\title{
ANALISIS KONFLIK TOKOH UTAMA PADA FILM HARANI ADAT DALAM MEMBANGUN SUSPENSE
}

\author{
Muhammad Ali Mursid Alfathoni \\ Prodi Televisi dan Film \\ Fakultas Seni dan Desain Universitas Potensi Utama \\ Mhd.ali8mursid@gmail.com
}

\begin{abstract}
ABSTRAK
Penelitian ini tentang analisis konflik yang dialami oleh tokoh utama sehingga mampu membangun suspense pada film "Harani Adat". Film "Harani Adat" merupakan film yang diproduksi secara side stream oleh RMP Production. Film "Harani Adat" disutradarai oleh Sulaiman S. Skenario film "Harani Adat" ditulis oleh Bullah Lubis. Film "Harani Adat" menceritakan tentang norma adat yang berlaku dalam kehidupan sosial budaya masyarakat Angkola-Mandailing. Dalam penelitian ini peneliti menggunakan analisis secara kualitatif dengan pendekatan deskriptif. Melalui analisis dan pendekatan yang digunakan dalam penelitian ini akan ditemukan bentuk konflik yang menjadi penghambat tokoh utama dalam mewujudkan misinya. Konflik yang dialami oleh tokoh utama terdiri dari konflik internal (batin), eksternal, dan situasional. Konflik yang dialami tokoh utama pada film "Harani Adat" mampu memicu suspense dalam alur cerita. Suspense pada film "Harani Adat" terjadi dibeberapa scene sehingga mampu membuat film tersebut menarik untuk ditonton. Alur konflik yang terdapat pada film "Harani Adat" saling berkaitan dan disesuaikan dengan struktur dramatik. Adanya alur cerita dan dikontrol dengan struktur dramatik membuat penonton akan menduga ending cerita melalui suspense yang muncul.
\end{abstract}

Kata kunci: Film, Harani Adat, Konflik, Suspense.

\begin{abstract}
This research on the analysis of conflicts experienced by the main character is able to build suspense in the film "Harani Adat". The movie "Harani Adat" is a film produced on a side stream by RMP Production. The movie "Harani Adat" was directed by Sulaiman S. Screenplay by "Harani Adat" written by Bullah Lubis. The Film "Harani Adat" tells about the customary norms that apply in the social life of the culture of Angkola-Mandailing society. In this research researchers used the analysis qualitatively with a descriptive approach. Through the analysis and approach used in this study will be found a form of conflict that becomes the main character inhibitors in realizing its mission. The conflicts experienced by the main character consist of internal, external, and situational conflicts. The main character conflict in the movie "Harani Adat" was able to trigger suspense in the storyline. Suspense on the film "Harani Adat" occurred in several scenes so that it was able to make the film interesting to watch. The conflict plot contained in the movie "Harani Adat" is interconnected and adapted to the dramatic structure. The existence of a storyline and controlled by a dramatic structure makes the viewer suspect the ending of the story through the suspense that appears.
\end{abstract}

Keywords: Film, Harani Adat, conflict, suspense. 


\section{PENDAHULUAN}

Pada saat sekarang ini, film sebagai salah satu media hiburan mengalami perkembangan yang sangat pesat. Perkembangan tersebut ditandai dengan maraknya berbagai jenis judul film beredar dipasaran. Film yang beredar dipasaran ada beragam jenis dan genre. Adanya keberagaman genre tersebut tentu setiap orang dapat memilih untuk menonton film yang mereka suka. Film tersebut diproduksi baik skala main-stream maupun side stream. Film main stream merupakan sebuah film yang diproduksi dan distribusikan ke penonton melaui jalur studio film $(\mathrm{PH})$ ke bioskop dalam lingkup nasional maupun internasional. Akan tetapi, film side stream merupakan film yang diproduksi dalam lingkup komunitas, sekolah, perguruan tinggi, dan di distribusikan ke penonton melalui jalur mandiri dalam skala terbatas. Selain itu, film yang diproduksi secara side stream juga mampu memiliki kualitas dan memiliki daya saing dengan film main stream pada umumnya.

Keberadaan film sebagai media hiburan, tentu dibangun berdasarkan plot yang sudah ditentukan sebelumnya. Adanya plot dalam film, tentu bertujuan untuk menghasilkan visual yang bagus agar tidak membosankan ketika film tersebut ditonton. Aminuddin (2009: 83) menyebutkan bahwa alur diartikan bentuk dari rangkaian cerita yang terbentuk oleh rangkaian peristiwa sehingga menjalin satu cerita. Peristiwa yang terjadi dalam sebuah film tentu dihadirkan oleh para pelaku yang terdapat pada sebuah cerita maupun film. Dengan demikian, alur merupakan bentuk jalinan peristiwa satu dengan lainnya yang saling berhubungan yang menimbulkan sebab akibat dalam sebuah cerita maupun film. Setiap film baik film main stream maupun side stream tentu didalam film tersebut terdapat plot. Menurut Elsaesser dan Hagener (2010: 43) The plot is the structured set of all causal events as we see and hear them presented in the film itself. Adanya plot dalam film, tentu hubungan sebab akibat yang tercerminkan dalam film tersebut dapat dipahami oleh penonton maksud dan tujuannya. Plot yang menggambarkan hubungan antar scene dalam film tentu dibuat agar film tersebut tidak membosankan ketika ditonton. Pada umumnya, dalam sebuah film plot yang mampu membuat penonton menggugah emosi adalah konflik. Konflik pada film yang terlihat dari pergerakan pemain dipicu dari berbagai faktor. Faktor tersebut dapat berasal dari faktor internal (diri sendiri) maupun eksternal (lingkungan, keluarga, dan sebagainya). Konflik merupakan bentuk pertingkaian ataupun pertentangan yang tercerminkan dalam plot sebuah film. Menurut Delimayanti, dkk (2018: 20) bahwa konflik merupakan bentuk pertentangan atau bentuk pertingkaian yang terjadi di dalam sebuah drama. Selain itu, bahwa film pada umumnya tentu sangat erat hubungannya dengan tema, cerita, setting, karakter, serta segala sesuatu yang mencerminkan suasana kehidupan nyata yang tersajikan secara visual (Pratista, 2008: 14).

Film Harani Adat merupakan sebuah film yang diproduksi secara indiependent oleh RMP Production. Film tersebut diproduksi pada tahun 2016 yang disutradarai oleh Sulaiman S. Skenario film "Harani Adat" ditulis oleh Bullah Lubis. Untuk alur cerita yang terdapat dalam film "Harani Adat" disadurkan dari kisah yang dialami oleh Sulaiman S selaku sutradara pada film "Harani Adat". Film "Harani Adat" tergolong dalam film indie yang memiliki alur cerita yang menarik untuk ditonton. Alur cerita pada film "Harani Adat" mencerminkan suatu realitas kehidupan tentang norma adat istiadat yang ada pada masyarakat Tapanuli Selatan yang bersuku Angkola-Mandailing. Film bagian dari produk kebudayaan yang mampu memvisualisasikan realitas kehidupan tentu mampu membuat penonton tergugah ketika menyaksikan adegan demi adegan yang terdapat pada sebuah film. Hal tersebut senada dengan pendapat Pratista (2008: 3) bahwa penonton secara tidak langsung memiliki peran aktif baik dalam keadaan sadar maupun tidak untuk memahami sebuah film yang sedang ditonton. 
Pada film "Harani Adat" suspense dibangun melalui konflik yang dialami oleh tokoh utama. Konflik tersebut terbentuk dari struktur dramatik yang ada dalam plot/alur yang terdapat didalam film "Harani Adat". Adanya teknik suspense yang terapkan dalam film "Harani Adat" menjadi sebuah tontonan yang menarik. Selain itu, akan membuat penonton menerka-nerka ending yang akan dialami oleh tokoh utama ketika mengalami berbagai konflik dalam film untuk mencapai suatu keinginan. Konflik yang menonjol pada film "Harani Adat" terlihat pada tokoh utama yang diperankan oleh Dapot. Dapot harus menentang aturan adat dan pamannya demi untuk menikahi Laila. Sulaiman S selaku sutradara mampu mengemas konflik yang dialami oleh Dapot dengan sebaik mungkin sehingga film "Harani Adat" memiliki suspense yang menarik untuk dikaji dan dibahas lebih luas. Untuk menguraikan suspense pada film "Harani Adat" peneliti menggunakan metode penelitian kualitatif dan pendekatan deskriptif. Selain itu, untuk mendukung agar mendapatkan informasi yang mendalam tentang suspense pada film "Harani Adat" peneliti juga menggunakan teori plot.

\section{II.STUDI LITERATUR}

Hasil penelitian Lluís Sayol dan Àngel Colom Pons dalam jurnal International Journal of Film and Media Arts yang berjudul "Suspense mechanics in narrative video Games"tahun 2017. Pada penelitian ini, Lluís Sayol dan Àngel Colom Pons menggunakan model analisis perspektif focalization dan sosok pemain untuk mendeskripsikan suspense pada sebuah video game. Lluís Sayol dan Àngel Colom Pons mencoba untuk memahami hubungan antar pemain, pemain dan efek emosional yang ditimbulkan. Lluís Sayol dan Àngel Colom Pons melakukan penelitian ini bertujuan untuk mendapatkan pemahaman yang lebih dalam dari sebuah narasi audiovisual. Hasil yang Lluís Sayol dan Àngel Colom Pons dapatkan bahwa suspense (ketegangan) yang terdapat dalam video game jika dilihat dari perspektif narasi, bahwa suspense pada permainan video game tidak seperti suspense pada sebuah film. Akan tetapi, suspense pada video game lebih terhadap kesulitan yang didapat dari permainan sebelumnya. Persamaan penelitian ini dengan penelitian peneliti adalah sama-sama mendeskripsikan bentuk suspense pada sebuah objek. Akan tetapi, titik perbedaan terletak pada objek kajian. Penelitian Lluís Sayol dan Àngel Colom Pons menggunakan objek penelitian video game. Adapun objek kajian peneliti adalah film "Harani Adat".

Rujukan peneliti selanjutnya adalah, hasil penelitian Lisdia Rahma Delimayanti, Endang Mulyaningsih dan Lilik Kustanto yang berjudul "Analisis Peran Konflik Tokoh Utama Dalam Membangun Suspense Pada Film "AMORES PERROS" pada tahun 2018. Penelitian ini bertujuan untuk mengetahui bentuk konflik yang terjadi terhadap tokoh utama dan bentuk penerapannya dalam membangun suspense. Adapun hasil yang didapat oleh Lisdia Rahma Delimayanti, Endang Mulyaningsih dan Lilik Kustanto bahwa pada film "amores perros" memiliki beraneka ragam konflik dan terstruktur dengan sangat apik. Pada film "amores perros" konflik yang dialami oleh tokoh utama beragam jenis seperti konflik batin, situasional, bahkan konflik sosial. Adanya berbagai macam konflik tersebut suspense timbul dan berpusat pada saat tokoh utama mengalami kecelakaan dan sesudah kecelakaan. Penelitian ini dengan penelitian yang dilakukan oleh peneliti memiliki persamaan dalam objek kajian dan aspek permasalahan yang dikaji. Adapun titik perbedaan terletak pada judul objek film yang diangkat dan diteliti/kaji.

Penelitian yang dirujuk oleh peneliti selanjutnya adalah penelitian Irma Oktarica Firziandini, Dwi Haryanto, dan Mochamad Ilham. Penelitian tersebut berjudul "Analisis Struktur Naratif Pada Film "Merry Riana Mimpi Sejuta Dollar" Dalam Membangun Adegan Dramatik" tahun 2018. Penelitian ini membahas dan bertujuan untuk mengetahui 
bentuk struktur naratif yang berfungsi untuk membangun adegan dramatik dalam film "Merry Riana Mimpi Sejuta Dollar". Hasil penelitian yang didapat oleh Irma Oktarica Firziandini, Dwi Haryanto, dan Mochamad Ilham bahwa pada film "Merry Riana Mimpi Sejuta Dollar" terdapat unsur dramatik seperti konflik, suspense, curiosity, dan surprise. Selain itu, unsur tersebut didukung oleh ruang dan waktu serta tujuan tokoh utama. Persamaan penelitian ini dengan penelitian penulis terletak pada objek kajian yang samasama mengambil objek film. Selain itu, penelitian ini juga mendeskripsikan struktur naratifnya untuk mendapatkan unsur-unsur dramatik. Adapun perbedaanya terletak pada judul objek film yang diangkat serta permasalahan kajian. Peneliti lebih kearah mendeskripsikan bentuk suspense yang muncul oleh tindakan yang dilakukan oleh tokoh utama.

\section{PEMBAHASAN}

Film "Harani Adat" merupakan sebuah film yang tergolong laris dipasaran dan dijual dalam bentuk kepingan VCD di daerah Sumatera Utara. Film "Harani Adat" dikemas dengan nuansa sosial budaya masyarakat Tapanuli Selatan. Menurut Sulaiman S selaku sutradara film "Haran Adat" menyatakan bahwa hasil penjualan film "Harani Adat" mencapai 40.000 keping VCD. Kepingan VCD tersebut terdiri dari Part I dan Part II (Wawancara, tanggal 23 Juni 2018). Pada "Harani Adat" konflik terjadi ketika Dapot (Tokoh Utama) mengenal seorang perempuan diperantauan. Perempuan tersebut bernama Laila. Setelah lama berkenalan dan menjalin hubungan asmara. Dapot ingin memperkenalkan Laila kepada keluarganya. Tujuan Dapot mengenalkan Laila kepada keluarganya karena ingin menikahi Laila. Ketika Leman (Paman Dapot) mengetahui perempuan yang ingin dinikahi Dapot tersebut adalah Laila membuat Leman merah kepada Dapot dan keluarga Dapot. Leman yang masih dalam keadaan marah menghardik Dapot dan Laila. Ketika melihat hal tersebut, Torkis (Ayah Dapot) lantas menocoba untuk menenagkan Leman dan bertanya kenapa Leman tiba-tiba marah ketika melihat Dapot dan Laila. Dalam keadaan penuh amarah Leman mengatakan kalau Dapot tidak boleh menikahi Laila. Leman mengatakan bahwa Laila tergolong keluarga sedarah yang tidak boleh dinikahi oleh Dapot. Leman mengatakan bahwa jika hubungan Dapot dan Laila masih sangat dekat dalam tataran hukum adat. Menurut Bisri (2012: 112) menyatakan bahwa hukum adat merupakan sebuah sistem aturan yang berlaku dalam kehidupan masyarakat Indonesia. Hukum tersebut dapat berasal dari adat kebiasaan yang terjadi disuatu masayarakat. Adanya hal tersebut, membuat masyarakat secara turub temurun mentaati dan mengikuti aturan tersebut sehingga menjadi sebuah tradisi.

Untuk mendeskripsikan bentuk konflik yang memunculkan suspense pada film Harani Adat peneliti menggunakan analisis kualitatif dengan pendekatan deskriptif. Melalui analisis dan pendekatan tersebut tentu permasalahan yang terdapat pada objek penelitian dapat diuraikan dengan sebaik mungkin. Metode penelitian kualitatif sering juga disebut sebagai metode penelitian naturalistik karena penelitiannya dilakukan pada kondisi yang alamiah (natural setting); disebut juga metode etnographi, karena pada awalnya metode ini lebih banyak digunakan untuk penelitian bidang antropologi budaya; disebut sebagai metode kualitatif, karena data yang terkumpul dan analisanya lebih bersifat kualitatif (Nurdin dan Hartati: 41).

\section{III.1. Konflik Tokoh Utama Pada Film Harani Adat Dalam Membangun Suspense}

Untuk melihat konflik yang dialami oleh tokoh utama pada film "Harani Adat" penulis mengawali dengan awal mula Dapot berkenalan dengan Laila dan ingin 
menikahinya. Dapot berkenalan dengan Laila disebuah tokoh yang sedang ia kelola. Adapun bentuk dialog perkenalan Dapot dan Laila seperti berikut ini:

Dapot: Eeh dek. Kalau boleh tahu adek ada marga nya?

Laila: Ia bang... aku boru Regar. Abang marga nya apa?

Dapot: Harahap dek. Kelvin astar harahap.

Dari dialog diatas terihat bahwa Dapot menyembunyikan identitasnya dan menyebutkan nama samaran. Selain itu, dapot hanya sekedar menyebutkan marga semata dan tidak menjelaskan panjang lebar dari mana asal usulnya kepada Laila. Begitu juga dengan Laila yang tidak bertanya lebih jauh. Dalam masyarakat Tapanuli Selatan pada umumnya jika baru pertama kali bertemu mereka saling menanyakan marga serta asal usul yang dikenal dengan istilah martarombo. Martarombo merupakan bentuk komunikasi interpersonal yang dilakukan oleh dua orang atau kelompok yang saling bertanya asal usul suatu marga dan hubungannya dengan kelompok lainnya. (Sihombing, 1986: 103). Hubungan Dapot dan Laila semakin berlanjut dan membuat mereka berdua memutuskan untuk menikah. Dapot mengutarakan maksud ingin menikahi Laila kepada kedua orang tuanya. Namun, kedua orang tua Dapot belum bisa memutuskan dan memberikan jawabanya sebelum perihal tersebut dibicarakan kepada Leman selaku adik kandung Martunis (Ayah Dapot).

Martunis beserta keluarganya segera menuju rumah Leman untuk membicarakan keinginan Dapot untuk menikahi Laila. Leman sangat senang mendengar Dapot keponakan semata wayangnya ingin menikah. Namun, ketika mengetahui perempuan yang ingin dinikahi Dapot adalah Laila, membuat Leman sangat marah bahkan berkata kasar dan menghardik Martunis. Leman mengatakan kalau keluarga Martunis tidak tahu akan tataran hukum adat yang berlaku dalam adat istiadat masyarakat Tapanuli Selatan. Leman menyatakan bahwa Laila merupakan adik sepupu dari istrinya. Leman berkeyakinan dan berpegang teguh bahwa Laila masih tergolong kerabat dekat dengannya dan masih berhubungan darah yang disebabkan karena pernikahan. Leman dengan penuh amarah mnenjelaskan perihal tersebut panjang lebar dihadapan Martunis dan keluarganya. Adegan tersebut terlihat pada pada capture film "Harani Adat" dibawah ini:

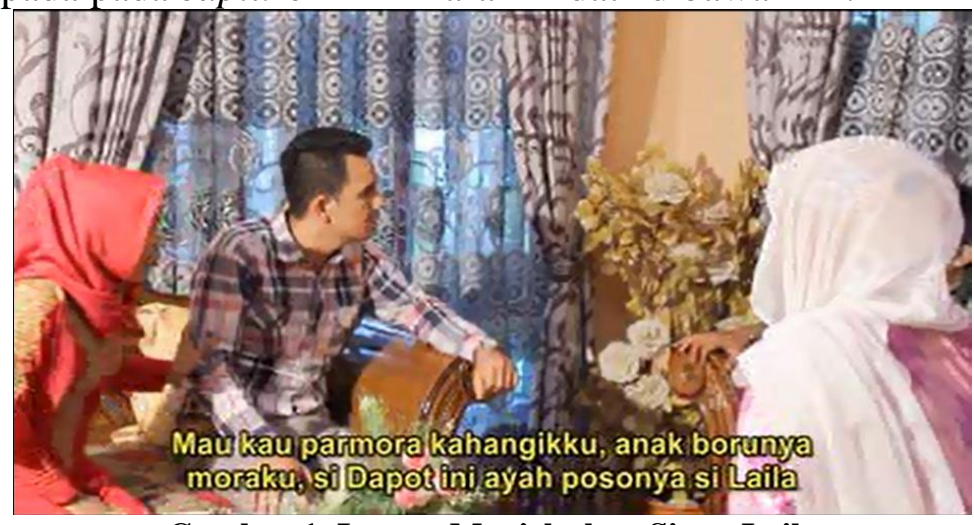

Gambar 1. Leman Menjelaskan Siapa Laila

(Sumber : Ali Mursid. Capture film Harani Adat, 2019)

Setelah Leman menjelaskan siapa sebenarnya Laila, Leman lantas mengusir Martunis dan keluarga untuk segera pulang. Leman lepas kendali akibat ulah Dapot yang tidak mencari informasi terlebih dahulu siapa sebenarnya Laila. Berawal dari adegan tersebut membuat konflik tokoh utama semakin memuncak agar dapat mencapai tujuannya. Dapot selaku tokoh utama tentu memiliki motivasi maupun tujuan agar keinginannya untuk menikahi Laila bisa tercapai. Tahapan suspense pada film "Harani Adat" mulai terlihat semenjak Dapot dan Laila berkenalan sampai konflik yang terjadi 
antara keluarganya dengan Leman. Proses terlihatnya konflik yang akan terjadi pada film dikenal dengan sebutan adegan pertanda atau foreshadowing. Adanya tersebut dapat dipandang sebagai tanda-tanda akan terjadinya sebuah konflik atau peristiwa besar (lebih serius) yang akan dialami oleh tokoh utama (Nurgiyantoro, 2002: 135). Akibat perseteruan antara keluarga Dapot dan Pamannya membuat Dapot harus menghadapi konflik situasional. Dimana Dapot harus mampu melewati sistuasi yang terjadi di dalam keluarganya agar dapat menikahi Laila tanpa hambatan. Konflik situasional yang dialami oleh Dapot pada scene yang terdapat pada capture diatas tentu mampu mengiring penonton berdebar dan menanti resiko yang akan dihadapi oleh Dapot selaku tokoh utama dalam menghadapi konflik yang sedang dialaminya. Biran menyatakan (2006: 114) bahwa penonton tentu bisa merasakan tegang jika mereka bisa dibuat ragu, apakah protagonis bisa atau tidak menghadapi hambatan. Jika gagal tentu ada resiko bahaya yang dihadapinya.

Setelah peristiwa yang terjadi antara Dapot dan Leman, membuat Dapot menjadi brutal dan siap melakukan apa saja demi mencapai ambisinya untuk menikahi Laila. Dapot dinasehati oleh Martunis agar tidak melakukan hal-hal yang diluar batas dan aturan adat. Namun, nasehat tersebut tidak dihiraukan oleh Dapot. Untuk menenangkan drinya agar bisa melupakan Laila, Dapot melakukan berbagai cara termasuk minum minuman keras. Dapot yang sudah tidak terkendalikan membuat Martunis putus asa dan mengusir Dapot dari rumah. Akibat konflik batin yang dialaminya membuat Dapot nekad untuk lari dari rumah orang tuanya. Selain itu, Dapot mengatur rencana agar bisa berjumpa dengan Laila. Dapot juga berencana untuk membunuh Leman yang sudah menghalaginya untuk menikahi Lailai dan sudah menghina kedua orang tuanya. Dapot mendatangi rumah Laila dengan penuh harapan agar Laila masih mencintainya. Adanya berbagai rencana yang ingin dilakukan oleh Dapot tentu mampu membuat suspense semakin meningkat dan tentu penonton akan menduga-duga apakah Dapot mampu melakukan semua rencana yang ia rencanakan. Unsur suspense akan mendorong, menggelitik, dan memotivasi pembaca atau penonton untuk tetap setia mengikuti cerita, untuk jawab rasa ingin tahu terhadap kelanjutan akhir dari cerita (Nurgiyantoro, 2002: 134).

Suspense kembali muncul ketika Laila yang sedang termenung disebuah kursi dihadapan rumahnya kaget melihat kedatangan Dapot yang sudah menghilang beberapa bulan dan tidak pernah ada memberi kabar apapun. Laila histeris. Akan tetapi, Dapot mencoba untuk meyakinkan Laila dan menjelaskan semua yang terjadi. Mendengar penjelasan Dapot membuat Laila luluh. Dapot mengutarakan maksud kedatangannya menjumpai Laila untuk mengajaknya kawin lari. Kawin lari merupakan solusi agar cinta mereka direstui oleh pihak keluarga baik keluarga Dapot maupun keluarga Laila. Berikut bentuk dialog ketika Dapot mengajak Laila kawin lari yang terdapat pada scene 16 dalam film "Harani Adat".

16. Ext. Lapangan. malam

Dapot:

"Songonon do anggi, ngadong nasetuju di hubungan ta, tai inda bisa au malupahonko...

Onpe, anggo nabetul-betul roha mu tu au. KAWIN LARI MAITA. (begini dek, adikkan tahu kalau tidak ada yang setuju dengan hubungan kita ini, tapi aku tidak bisa melupakan dirimu... sekarang kalau kamu betul-betul mencintai aku...ayo kita kawin lari” (Sumber. Film Harani Adat. 2019). 
Mendengar penyataan tersebut membuat Laila sangat terkejut. Namun, Dapot terus mencoba meyakinkan Laila akan tujuan mereka yang ingin hidup berdua dalam ikatan pernikahan. Dapot berani mengambil resiko dan menerobos aturan adat yang diyakini oleh Leman. Hal tersebut dilakukan oleh Dapot karena konflik batin yang ia alami tidak mempu ia bendung sehingga mampu memunculkan suspense akan tindakan yang diambil dan dilakukan oleh Dapot. Suspense yang muncul ketika Dapot menyakinkan Laila untuk menerima ajakannya untuk kawin lari. Suspense semakin meningkat ketika Dapot menerima persyaratan sumpah yang diajukan Laila kepadanya dengan meneteskan darah diatas sapu tangan yang bertuliskan nama masing-masing. Ketika melihat adegan tersebut tentu suspense yang terjadi pada film Harani Adat tentu akan terlihat bahwa Dapot selaku tokoh utama akan mencapai tujuan yang ia inginkan.

Pada adegan tersebut tangga dramatik mulai terlihat turun dan mencerminkan bahwa ending cerita bahwa protagonis mampu mewujudkan impiannya tanpa harus menghadapi rintangan yang lebih sulit. Adapun bentuk capture adegannya seperti terlihat pada gambar dibawah ini:

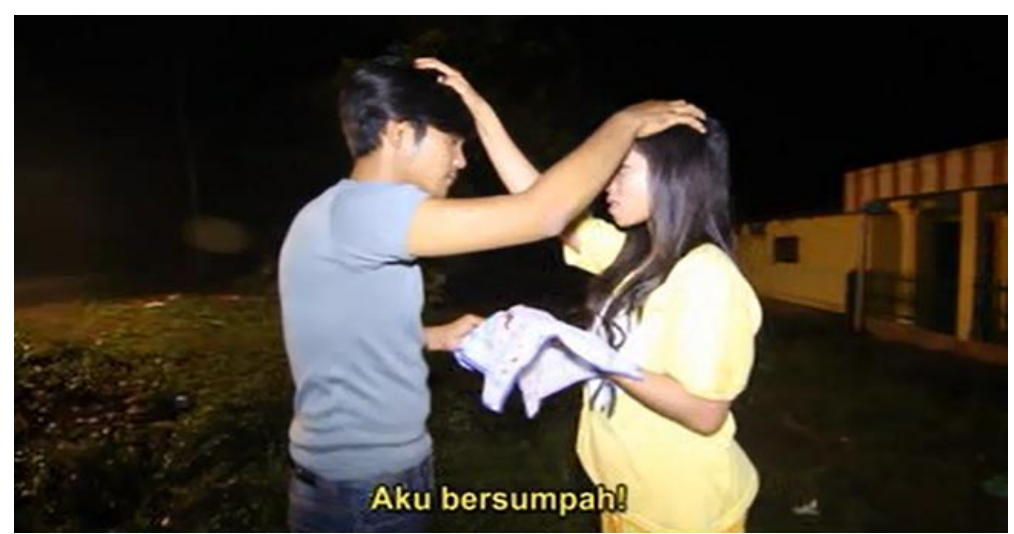

Gambar 2. Dapot dan Laila mengikat janji dengan sumpah (Sumber : Ali Mursid. Capture film Harani Adat, 2019)

Pada adegan diatas terlihat tokoh utama kembali membuat suspense yang membuat penonton bertanya-tanya akan makna tetesan darah diatas sapu tangan bertuliskan nama mereka. Tetesan darah yang mereka jadikan saksi menujukkan bahwa cinta mereka tidak akan pisah dipisahkan oleh siapapun kecuali maut yang memisahkan. Ibarat darah yang mengalir dalam tubuh mereka seperti itu lah kuatnya cinta mereka. Selama darah mengalir dalam tubuh mereka, selama itulah mereka akan mempertahankan cinta suci mereka walaupun berbagai rintangan datang menghampiri. Dapot menyadari bahwa langkah yang ia ambil untuk membawa Laila kawin lari merupakan tindakan yang sangat fatal.

Rencana awal berhasil Dapot lakukan dan membawa Laila jauh dari rumahnya dan menuju kampung halamannya agar bisa menikah. Namun, keinginan tersebut tidak semulus rencana yang ia duga. Konflik situasional kembali menghampiri Dapot. Dapot harus berhadapan dengan keluarganya dikampung atas tindakan yang ia lakukan. Akibat tindakan yang ia lakukan tentu membawa aib yang sangat besar bagi keluarga mereka yang masih menjunjung tinggi aturan adat istiadat Tapanuli Selatan. Akan tetapi, itu merupakan bentuk suspense yang dimuncul akibat tokoh utama berusaha mewujudkan keinginannya. Ketika Martunis mengetahui hal tersebut, Martunis segera mengambil tindakan agar tujuan dan rencana yang dilakukan oleh Dapot gagal. Martunis membawa Laila kembali pulang rumah orang tuanya dan Martunis memohon maaf atas tindakan yang dilakukan oleh Dapot. Orang tua Laila menyatakan bahwa Dapot itu merupakan anak bagi Laila dan Laila adalah bibinnya Dapot. Jika sudah terjadi hubungan yang demikian sudah tidak 
sepantasnya Dapot menikahi Laila. Hal tersebut sesuai dengan aturan adat yang tercerminkan dalam aturan Dalihan $\mathrm{Na}$ Tolu yang ada dalam adat istiadat masyarakat Tapanuli Selatan. Dalihan Na Tolu dikenal dengan kahanggi, anak boru dan mora yang merupakan simbol tiga kelompok masyarakat adat yang bekerja sama dalam menyelesaikan urusan adat, seperti: upacara siriaon yang meliputi peristiwa perkawinan dan kelahiran, upacara siluluton yang meliputi peristiwa kematian dan musibah (Husniah Pulungan, 2015: 310).

Dapot tidak menyerah dengan konflik yang menghadangnya. Dapot kembali meluncurkan aksi sehingga suspense pada film "Harani Adat" semakin menegangkan. Akibat konflik situasional yang dihadapi Dapot tentu tangga dramatik pada film Harani Adat kembali naik dan mengiringi protagonis dalam alur cerita agar mampu menyelesaikan segala hambatan yang ia alami. Ketegangan semakin terasa jika penonton tahu hambatan yang dihadapi oleh tokoh utama cukup besar dan keberhasilannya semakin kecil (Lutters, 2006: 101). Dapot kembali mendatangi rumah Laila. Namun, Dapot mendapati Laila sedang bersama ibunya. Laila dinasehati oleh ibunya siapa sebenarnya Dapot dan ibu Laila akan segera membawa Laila jauh dari kampung halamanya agar tidak membuat malu keluarga. Adegan tersebut tentu membuat penonton menduga-duga bahwa bahwa protagonis akan kesulitan untuk mewujudkan impiannya. Akan tetapi, Dapot tidak menghiraukan siapapun demi mendapatkan Laila kembali. Dapot membawa paksa Laila dan berusaha untuk bisa membawa Laila kembali kabur Ibunya Laila mencoba untuk menghadang. Tanpa melakukan perlawanan yang ekstra, Dapot berhasil membawa Laila kabur. Pada adegan ini penonton kembali disuguhkan dengan suspense yang mencekap akibat tindakan yang dilakukan oleh protagonis dengan membawa paksa Laila dari hadapan ibunya. Adegan tersebut terlihat pada capture film "Harani Adat" berikut ini:

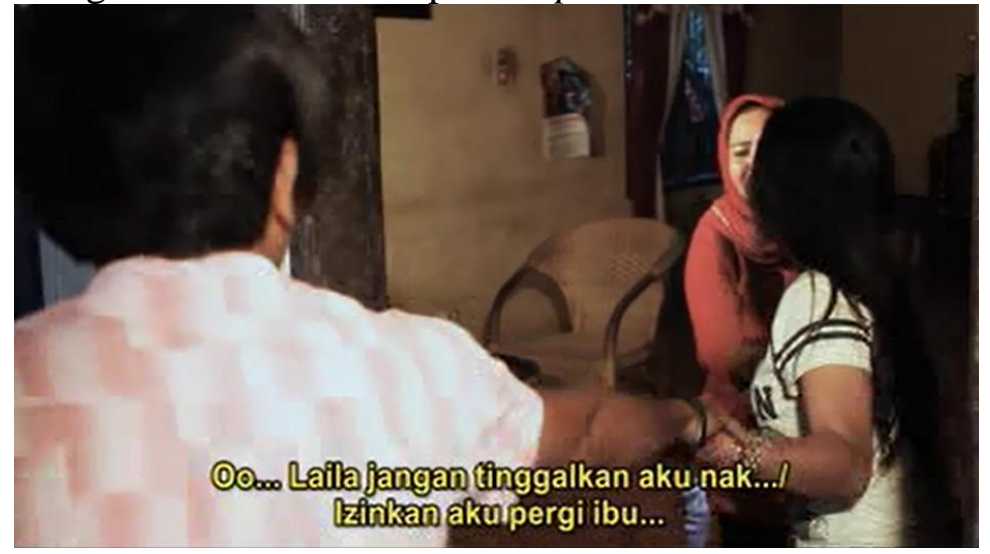

Gambar 3. Dapot tidak menghiraukan Kedudukan Ibu Laila (Sumber : Ali Mursid. Capture film Harani Adat. 2019)

Adegan demi adegan dalam film "Harani Adat" selalu ada suspense yang dimunculkan oleh tokoh utama. Ketika Dapot berhasil membawa Laila kabur untuk kedua kalinya. Akan tetapi, langkah dan usaha Dapot tidak sampai disitu saja. Dapot harus berhadapan dengan Leman yang sangat keras menentang keinginan Dapot untuk menikahi Laila. Leman mengetahui kalau Dapot membawa Laila lari dari rumah ketika Leman pulang dari kantor dan melihat Dapot dan Laila sedang berdiri dipinggir jalan raya menunggu angkutan umum agar bisa lari lebih jauh. Dapot menyadari kehadiran Leman sehingga suspense kembali mencuat ditengah asmara cinta Dapot dan Laila. Leman keluar dari mobilnya dan menghadang Dapot dan Laila. Akan tetapi, Dapot membawa Laila lari menuju semak belukar agar Leman tidak mengejar mereka. Leman yang memiliki berpegang teguh terhadap aturan adat dan bertanggung jawab terhadap segala tindakan yang dilakukan oleh anggota keluarganya tidak menyerah mengejar Dapot dan Laila agar 
mereka tidak sampai jauh melangkah dan tidak melanggar aturan adat yang sudah dijaga dari dahulu oleh nenek moyang mereka. Hambatan yang akan dialami semakin lama semakin bertubi-tubi dan semakin membuat protagonis dalam posisi mengkhawatirkan. (Biran, 2006: 158).

Dapot dan Laila terdesak akibat kejaran Leman. Dapot dan Laila terhenti karena didepan mereka ada sungai yang sangat deras dan dalam. Adegan tersebut tentu membuat suspense semakin meningkat, dan penonton akan menduga apakah Dapot dan Laila akan nekad untuk melancarkan aksinya agar bisa bebas dari kejaran Leman. Melihat Dapot dan Laila terjebak dalam situasi yang menegangkan membuat Leman mengatakan agar mereka harus segera mengakhiri cinta mereka. Akan tetapi, Dapot tidak menghiraukan hal tersebut dan tetap pada prinsipnya ingin menikahi Laila walaupun harus melawan aturan adat dan pamannya. Penonton digiring agar merasa berdebar-debar dalam menanti resiko yang akan dihadapi oleh tokoh dalam menghadapi problemnya. Hal ini biasanya sering menimpa tokoh protagonis sehingga suspense pada penonton semakin tinggi tensinya, dibanding jika tokoh antagonis yang menghadapi hambatan. (Lutters, 2006: 102). Adegan tersebut telihat pada capture berikut ini:

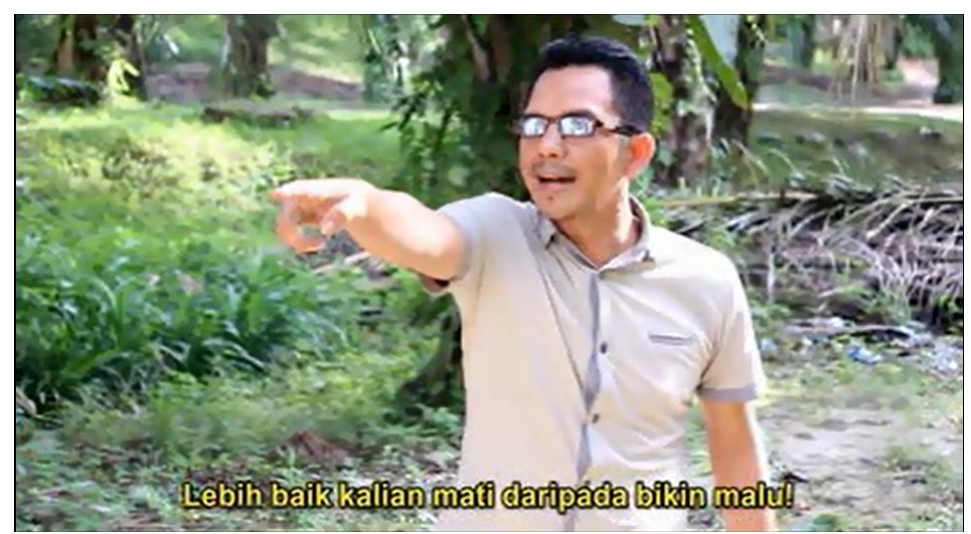

Gambar 4. Leman tidak memperdulikan ancaman Dapot untuk bunuh diri (Sumber : Ali Mursid. Capture film Harani Adat, 2019)

Dapot mengancam akan bunuh diri jika Leman terus melarang dan menghambat langkah mereka. Mendengar hal tersebut Leman mengatakan lebih baik mereka mati dari pada membuat malu keluarga. Mendengar hal tersebut Dapot dan Laila nekad terjun ke sungai. Adapun adegan Dapot dan Laila terjun ke dalam sungai seperti terlihat pada capture film "Harani Adat" dibawah ini:

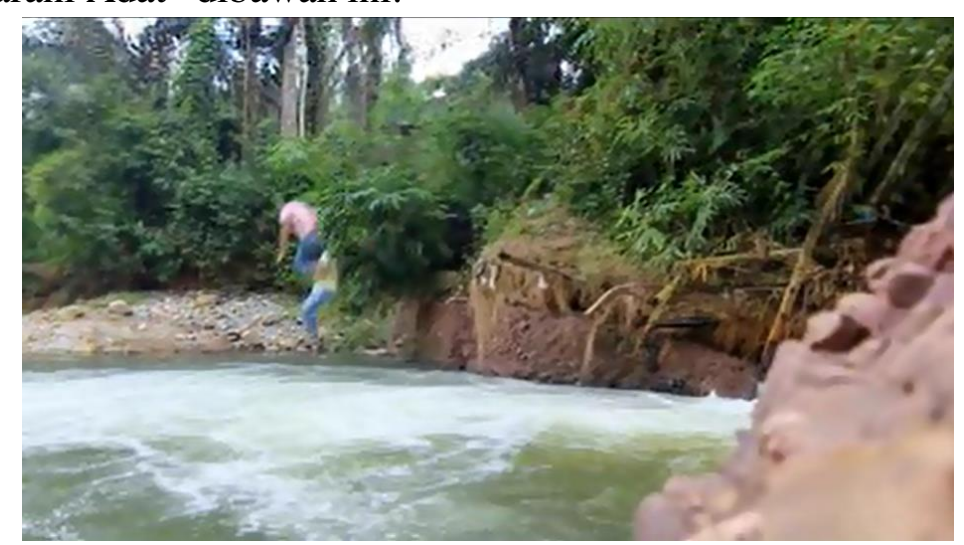

Gambar 5. Dapot dan Laila mencoba untuk bunuh diri (Sumber. Ali Mursid, Capture film Harani Adat, 2019) 
Adegan diatas merupakan suspense yang mencekam yang dialami oleh tokoh utama (Dapot). Dapot dengan penuh keberanian membawa Laila untuk terjun bersama ke dalam sungai agar terlepas dari kejaran Leman. Jika cermati, adegan suspense diatas memberikan makna bahwa jika sejati tidak lekang dan tergores oleh goncangan rintangan dan liku-liku kehidupan. Cinta sejati harus tetap dipertahankan walaupun maut menjadi taruhan. Ibarat batu dalam air tetap kokoh walau air terus mengalirinya. Setelah percobaan bunuh diri tersebut konflik batin Dapot kembali mencuat. Hal tersebut disebabkan Leman berhasil menyelamatkan Laila dan membawa Laila pulang kerumahnya. Mengetahui hal tersebut, Dapot kembali mengatur rencana. Rencana terakhir yang dilakukan Dapot adalah membunuh Leman agar tidak ada lagi penghalang dalam hidupnya. Berbagai rintangan dilalui oleh protagonis. Akan tetapi, penonton masih menunggu dan menebak bagaimana ending yang didapat oleh Dapot.

Akibat konflik batin yang semakin mencuat dan ditambah konflik eksternal membuat Dapot tidak bisa menimbang akibat yang ditimbulkan oleh rencana yang akan dia lakukan. Dapot menunggu dan menghadang mobil Leman yang melewati jalan raya yang biasa dilewati oleh Leman ketika pulang dan pergi kerja. Adegan tersebut terlihat pada scene 27 berikut ini:

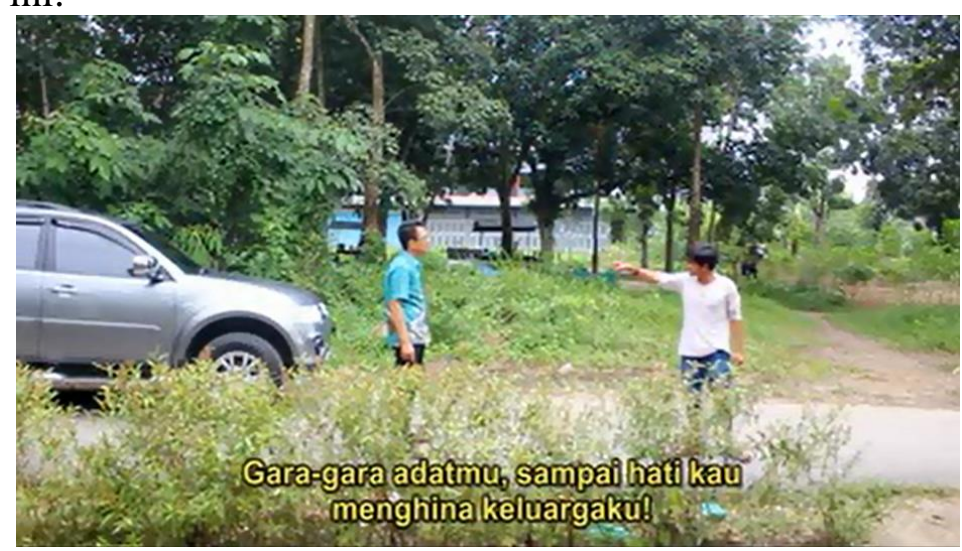

Gambar 6. Dapot Menghardik Pamannya

(Sumber. Ali Mursid, Capture film Harani Adat, 2019)

27. Ext. Pinggir jalan raya. Pagi

Dapot:

"Gara-gara ni adat mu,sampai hati ho manghina keluarga $k u$ !

(gara-gara adatmu, sampai hati kau menghina keluargaku !)”

\section{Leman:}

Anak durhako, naso mamboto adat !!!

(Anak durhaka, tidak tahu adat !!!)”. (Sumber. Film Harani Adat. 2019).

Pada scene 27 tersebut Dapot berhadapan dengan Leman yang selalu menjadi penghalang dalam kehidupannya untuk menikahi Laila. Ketika Dapot dan Leman saling berhadapan dan beradau mulut tentu membuat suspense yang muncul akibat konflik tokoh utama kembali mengambil bergejolak. Dapot dengan penuh amarah mengatakan bahwa hanya karena adat Leman rela menghina dan melarang hubungan yang ingin dijalinnya dengan Laila. Akan tetapi, Leman menghardik Dapot dan mengatakan Dapot tidak tahu aturan adat. Mendengar hal tersebut Dapot menghantam kepala Leman dengan bongkahan batu sehingga membuat Leman terjatuh dengan lumuran darah. Melihat hal tersebut Dapot menyadari kalau tindakan yang dia lakukan sudah diluar batas. Dapot dengan punuh perasaan bersalah lari meninggalkan Leman. Setelah kejadian tersebut suspense yang muncul yang disebabkan konflik yang dialami oleh tokoh utama perlahan-lahan mulai 
menemukan titik temu. Ketika tangga dramatik perlahan-lahan turun tentu terlihat ending yang didapat oleh tokoh utama. Dapot dan Laila harus berpisah karena adat. Dapot mengakui kesalahannya dan perlahan harus melupakan Laila dan menerima aturan adat yang diyakini oleh Leman selaku paman kandung Dapot. Karena Leman yang bertanggung jawab terhadap Dapot ketika ayahnya (Martunis) jika telah tiada.

\section{KESIMPULAN}

Suspense pada film Harani Adat muncul akibat konflik yang dialami oleh tokoh utama. Konflik muncul dan mencerminkan adanya resiko dan hambatan yang harus dilalui oleh tokoh utama. Konflik yang dialami oleh tokoh utama dapat berupa konflik situasional, internal (batin), dan eksternal. Konflik yang dialami oleh tokoh utama merupakan hambatan yang mampu menimbulkan keraguan dan tanda munculnya hambatan baru yang dialami oleh tokoh utama. Oleh karena itu, membuat ketidakpastian ending cerita pada film Harani Adat. Pada film Harani Adat konflik yang dialami oleh tokoh utama semakin komplek sehingga mampu membuat penonton penasaran kemampuan protagonis dalam melalui segala hambatan. Pada film Harani Adat alur konflik yang dialami oleh tokoh utama saling berkaitan sehingga suspense yang muncul tetap terjaga sesuai struktur tangga dramatik.

\section{DAFTAR PUSAKA}

\section{Buku:}

[1] Aminuddin (Ed). 2009. Pengembangan Penelitian Kualitatif dalam Bidang Bahasa dan Sastra.Malang: Yayasan Asih Asah Asuh.

[2] Biran, H. Misbach. Teknik Menulis Skenario Film Cerita. Jakarta: PT. Pustaka Jaya, 2006.

[3] Bisri, Ilham. 2012. Sistem Hukum Indonesia. Jakarta: Raja Grafindo.

[4] Elsaesser, Thomas dan Malte Hagener. 2010. Film Theory An Introduction Through The Senses. New York UK: Routledge.

[5] Lutters, Elizabeth. Kunci Sukses Menulis Skenario. Jakarta: Grasindo, 2006.

[6] Nurgiyantoro, Burhan. 2012. Teori Pengkajian Fiksi. Yogyakarta: Gadjah Mada University Press.

[7] Nurdin, Ismail dan Sri Hartati. 2019. Metodologi Penelitian Sosial. Surabaya: Media Sahabat Cendikia.

[8] Pratista, Himawan. 2008. Memahami Film. Yogyakarta: Homerian Pustaka.

[9] Pulungan, Husniah Ramadhani. 2015. "Mencegah Terjadinya Pernikahan Sedarah Dengan Memahami Partuturon Dalam Masyarakat Batak AngkolaMandailing”. Dalam Jurnal Fitrah, Volume 01, Nomor 2, Padangsidimpuan: Universitas Muhammadiyah Tapanuli Selatan.

[10] Sihombing, TM. 1986. Filsafat Batak Tentang Kebiasaan dan Adat Istiadat. Balai Pustaka: Jakarta. 


\section{Jurnal:}

[11] Delimayanti, Lisdia Raham, Dkk. 2018. “Analisis Peran Konflik Tokoh Utama Dalam Membangun Suspense Pada Film "AMORES PERROS”. dalam Sense. Vol. I, No.1, Yogyakarta: Institut Seni Indonesia Yogyakarta.

[12] Firziandini, Irma Oktarica, Dkk. 2018. "Analisis Struktur Naratif Pada Film Merry Riana Mimpi Sejuta Dollar Dalam Membangun Adegan Dramatik". dalam Publikasi Media. Vol. 6, No.2, Jawa Timur: Universitas Jember.

[13] Sayol, Lluís, dan Àngel Colom Pons . 2017. "Suspense mechanics in narrative video Games". dalam International Journal of Film and Media Arts. Vol. I, No.2, Facultat blanquerna, universitat ramon llull, Barcelona: spain. 